Papers and Proceedings of the Royal Society of Tasmania, Volume 116, 1982

(ms. received 22.1 .1982 )

\title{
A PYGMY RIGHT WHALE CAPEREA MARGINATA (GRAY, 1846) STRGNDED AT STANLEY, TASMANIA
}

by B.L. Munday, R.H. Green and D.L. Obendorf Mt Pleasant Laboratories, Department of Agriculture

Launceston South (B.L.M. and D.L.O.) and

Queen Victoria Museum and Art Gallery, Launceston

(with one plate and one table)

\section{ABSTRACT}

MUNDAY, B.L. GREEN, R.H. and OBENDORF, D.L., 1982 (31 viii): A F.ggmy right whale Caperea marginata (Grey, 1846) stranded at Stanley, Tasmania. Pap. Proc. R. Soc. Tasm., 116: 1-4.https://doi.org/10.26749/rstpp.116.1 ISSN 0080-4703. Department of Agriculture,

Launceston South and Queen Victoria Museum and Art Gallery, Launceston, Tasmania.

A pregnant female pygmy right whale, Caperea marginata (Gray, 1846) which stranded at west Beach, Stanley was examined within 24 hours of stranding. No significant pathological condition was detected in the carcase thus eliminating disease as the likely cause of stranding. However, the area is a notorious "whale trap", and it is therefore assumed that geographical and hydrological conditions accounted for the stranding. A number of interesting anatomical features are noted.

\section{INTRODUCTION}

On 10th September 1981 a female pygmy right whale Caperea marginata (Gray, 1846) was reported to have been stranded on West Beach, Stanley. Though dead, it was in fresh condition and had apparently come ashore the previous night. On the following morning, two pathologists, one from Mt Pleasant Laboratories and one visiting from the Ontario Veterinary College, Canada, drove to the site to examine the whale, gather data and obtain specimens for further investigation.

West Beach is on the western side of the Stanley Peninsula facing Perkins Bay, a shallow, semi-enclosed stretch of water with a sandy bottom. Owing to the topography, the tide can recede up to half a kilometre.

\section{OBSERVATIONS}

The whale was found to be lying on its left side and facing north (parallel to the beach). It had raw ulcers on the right mandible and recently healed ulcers above the right eye. There were numerous healed lesions overall and a bleeding wound posterior to the genital aperture. Dimensions of the whale are given in table I.

Upon dissection, the whale was found to be pregnant, carrying a female foetus of $600 \mathrm{gm}$ and of a total length of $0.38 \mathrm{~m}$. This foetus had a relatively well-developed head with a prominent mouth but lacked any indication of baleen development. The auditory meatus was barely discernible as a pin-prick indentation, the blowhole was open and the eyes just open as a $5 \mathrm{~mm}$ slit across the lower half of the eyeball. The entire skin (after preservation) was a pale cream with some pale grey subcutaneous shading. The presumed corpus luteum of pregnancy was present in the left ovary, which also had at least 14 corpora albicantes and 24 follicles up to $20 \mathrm{~mm}$ in diameter. The right ovary supported at least 31 follicles of up to $25 \times 40 \mathrm{~mm}$ and 11 corpora albicantes. No milk was present in the mammary gland. The placenta was villous epitheliochorial in structure. 


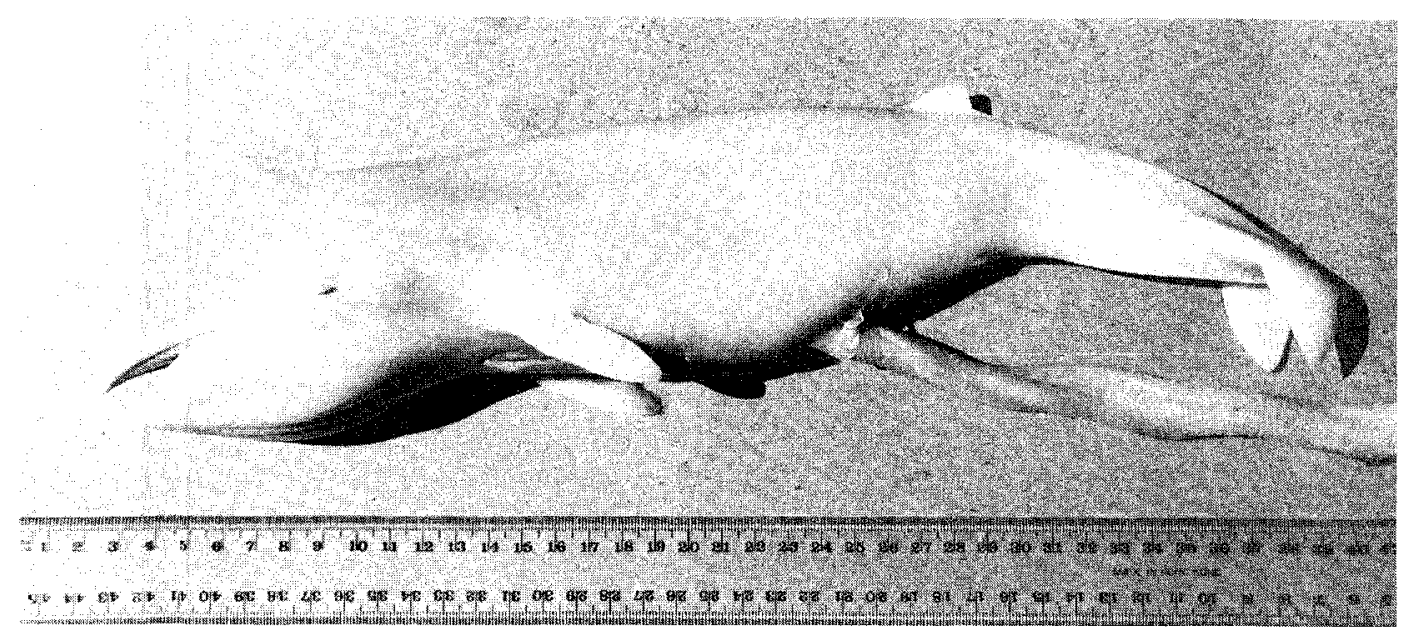

PLATE 1.- The female foetus which was taken from a pigmy right whale stranded at West Beach, Stanley, on 10th September 1981.

The larynx was surrounded by spongy tissues which communicated freely with both the oropharynx and the larynx itself. These tissues consisted of a connective tissue matrix permeated by channels lined by tall columnar epithelium and interspersed with areas of mucus-secreting glands. The ventral aspect of the larynx opened into a large diverticulum, which had a honeycombed internal surface lined by glandular epithelium and was surrounded by a thick muscular wall.

The stomach consisted of four distinct compartments. The first, and largest, was a simple diverticulum lined by non-glandular squamous epithelium. The tubiform second compartment was lined by mucus-secreting epithelium approximately $7.5 \mathrm{~mm}$ thick. Fundic (acid- and enzyme-secreting cells) glands lined the surface $0 \hat{i}$ the third compartment which had an epithelium approximately $15 \mathrm{~mm}$ thick. This organ was elongated with numerous transverse rugae on its mucosal surface. The fourth "stomach" was the smallest compartment. It was globose with a smooth glandular lining and was the point of entry of the single bile duct. This organ contained bile-coloured fluid and an "ambergris" soft-stone approximately $40 \mathrm{~mm}$ in diameter.

The caecum was $0.5 \mathrm{~m}$ long and had no taenia. Trematodes $7-8 \mathrm{~mm}$ in 1 ength were present in this organ and the proximal colon.

The head was removed and lodged with the Queen Victoria Muscum for skull preparation (Reg. No. 1981/1/165). The foetus (Reg. No. 1981/1/166) and ovaries (Reg. No. 1981/1/167) have been preserved in $4 \%$ formalin and also lodged with that museum. 


\section{DISCUSSION}

Previous reports of pygmy right whale strandings in Tasmania are limited. Davies and Guiler (1957) and Guiler (1978) presented results of their investigations into pygmy right whale strandings, including a number from Tasmanian waters, and provide some photographs of an adult female at Ralphs Bay on 23 rd June 1956.

Guiler (1961) recorded "the first evidence of breeding in this species" following his examination of a female (total length $6.37 \mathrm{~m}$ ) stranded at Eaglehawk Neck on the night of 26th June 1961. That specimen was carrying a foetus of $3 \mathrm{~kg}$ and of a total length of $0.6 \mathrm{~m}$ (lodged in the collections of the Zoology Department, University of Tasmania) and was thus five times the body weight and twice the total length of our stanley foetus. As our specimen was collected about 11 weeks later (seasonally) it appears that breeding in this species is not confined to a restricted season.

It is commonly asserted "that in the case of single strandings", the animal is generally in an advanced state of disease" (Bergin 1978). This was not the case with the pygmy right whale stranded at Stanley which was suffering from no detectable disease and carried very few parasites. It is more likely that the animal became disorientated in unfamiliar territory where sonar navigation could be impeded by the very gradual slope of the bottom. Indeed, strong northwesteriy winds, such as those occurring at the time, could be expected to back up water to the beach at high tide leading to completely erroneous feed-back from the animal's sonar soundings.

\section{ACKNOWLEDGEMENTS}

The authors wish to express their thanks for the assistance of Mr Robin King, National Parks and Wildlife Service, who reported the stranding and assisted with the onsite examination. Valuable assistance was also rendered by Dr I.K. Barker and Mr T. Black.

\section{REFERENCES}

Bergin, T.J., 1978: Stranded whales and dolphins. Proceedings No.36 of Courses for Veterinarians. The Post-Graduate Committee in Veterinary Science: $585-595$.

Davies, J.I. and Guiler, E.R., 1957: A note on the pygmy right whale Caperea marginata Gray. Proc. 2ool. Soc. Lond., 129: 579-589.

Guiler, E.R., 196l: A pregnant pygmy right whale. Aust. J. Sci., $24: 297$.

, 1978: Whale strandings in Tasmania since 1945 with notes on some seal reports. Pap. Proc. R. Soc. Tasm., 112: 189-213.

Norris, K.S., 1961: Standardised methods of measuring and recording data of the small cetaceans. J. Marm., 42: 471-476.

\section{ADDENDUM}

Another pregnant, pygmy right whale stranded at West Inlet, Perkins Bay, on 15.6.82. It is believed that this 6 metre animal came ashore on a very high tide the previous evening. This animal carried a foetus approximately two metres in length, further indicating that breeding is not confined to a restricted season. 
Measurements (mm) of a specimen of a female pygmy right whale stranded at west Beach, Stanley. The index numbers and dimensions are after Norris (1961).

Index

Number

\section{Feature}

Length to fluke notch

Length to mid-eye

Length to gape

Length to auditory meatus

Mid-eye to auditory meatus

$\mathrm{Mid-eye}$ to angle of gape

Mid-eye to mid-blowhole

Head length to blowhole

Length to pectoral

Length to tip of dorsal fin

Length to mid-umbilicus

Length to mid-genital slit

Length to mid-anus

Projection of lower jaw

Blubber thickness at mid-dorsum

Blubber thickness at mid-lateral

Blubber thickness at mid-ventrum

Half girth at axilla

Half girth at anus

Length of eye

Length of right mammary slit

length of left mammary slit

Length of genital slit

Width of blowhole

Length of blowhole

External auditory meatus

Length of pectoral, anterior

Length of pectora1, posterior

Width of pectora1, maximum

Height of dorsal fin

Length of dorsal fin base

Width of flukes

Anterior of fluke to notch

Depth of notch
Dimension

6450

1280

1040

1060

380

220

870

900

1890

4610

3470

4700

4920

180

60

20

40

1840

1210 
Papers and Proceedings of the Royal Society of Tasmania, Volume 116, 1982.

(ms. received 26.5 .1981 )

TASMANIAN TERTIARY FORAMINIFERIDA. PART 3.

DISCORBACEA (EPONIDIDAE) TO NONIONACEA

by Patrick G. Quilty

Antarctic Division, Kingston, Tasmania

(formerly Macquarie University)

(with three text-figures and six plates)

ABSTRACT

QUILTy, P.G., 1982 (31 viii): Tasmanian Tertiary Foraminiferida. Part 3. Discorbacea (Eponididae) to Nonionacea. Pap. Proc. R. Soc. Tasm., 116: 5-51. ISSN 0080-4703. Antarctic Division, Department of Science, Kingston, Tasmania.

This final part recording the Tasmanian Tertiary benthonic Foraminiferida documents the occurrence of 77 taxa of which 65 are previously defined, four are compared with previously defined species and eight are identified generically only. No species are new. Five forms recorded in parts $I$ and 2 are noted from a newly discovered sample from welcome River.

\section{INTRODUCTION}

This is the third part of a series of papers in this journal designed to document the Oligo-Miocene Foraminiferida of Tasmania and completes discussion of the benthic forms. The previous papers are those by Quilty $(1974,1977)$ and the conventions of occurrence are common to the three papers and are explained in Quilty (1974). Several new forms were described by Quilty (1980) are are simply recorded here. The stratigraphic framework of the Tasmanian Tertiary marine rocks was explained in Quilty (1972).

The classification of the Foraminiferida followed here is the same as in Quilty (1977) and is that proposed by Loeblich and Tappan (1974). Ages are quoted in terms of the $\mathrm{N}$ zones of Blow (1969). Occurrences are listed approximately from oldest to youngest.

Since the last of the series was published, another locality has been sampled and has yielded an interesting foraminiferid fauna. The locality is near the mouth of the Welcome River (figure 1) and was sampled by Mr G. van der Geer of the Geography Department, University of Tasmania. The rock specimen is catalogued in the collections of the Geology Department, University of Tasmania (UTGD) under the catalogue number UTGD 45979. The rock consists of a friable partly recrystallised bryozoal calcarenite. Preservation is quite good.

Several species from this new fauna are relevant to parts 1 and 2 of this series. They are:

Textuzaria gramen d'Orbigny $(\mathrm{r}$ ); Gaudryina convexa (Karrer) ( $\mathrm{r}$ ); Heronazzenia Zingulata (Burrows \& Holland) ( $r$ ); GZabratelZa erassa Dorreen ( $r$ ); Fileolina sp. indet. (r). 